\section{SHOULD WE EXPECT AN INCREASE IN CORPORATE ESPIONAGE IN THE PHARMACEUTICAL INDUSTRY OF TOMORROW?}

\section{INTRODUCTION}

Business information is of great importance in modern global society. The economy is conditioned by development, and development is again related to innovations that arise on the basis of new knowledge, research activities etc.. New knowledge represents important information for economic factors because the importance of such information can greatly change the course of activity in the market of certain goods or services. The exchange of information has been intensified through the development of technology, computer systems and modern servers. However, thanks to the development of technology, there has been a spread of ways and methods of abuse of technological systems, all in order to obtain certain information of importance in order to gain an advantage in the market or ensure a certain interest of stakeholders. There are different types of economic information of importance such as information on production, capacity, results, different production programs and production plans for a certain period of time, competition and suppression of the same, investment plans and the state of the stock market $(1,45-62)$. The aim of this paper was to show that one can expect increasing activity of corporate espionage in the biotechnology and pharmaceutical industry in the coming period, which is in line with the development of these industries.
DOI: $10.5937 / \operatorname{Rev} 2092037 \mathrm{~S}$

\section{SUMMARY}

Key words: pharmaceutical industry, patent protection, corporate espionage.

Corporate espionage is a process of obtaining classified information from business competitors for economic reasons and gaining an advantage over the competition. This paper is presenting an analysis of industry growth, investments in $R \& D$ and the total value of the investment estimating the possible existence of trends and activities of corporate espionage in the drug development industry. Some authors analyze the cost-effectiveness of corporate espionage compared to investing in $R \& D$, which if shows efficient - might be determining factor in broadening prohibited activities. The results of the analysis show that growing of corporate espoionage might be expected in the future due to the growing impact of these industries on society. 


\section{TRADE SECRET}

Business information is important, but not all business information are trade secrets at the same time. In the Republic of Serbia, a business secret is defined within the Companies Act as follows: "a business secret is information whose disclosure to a third party could harm the company, as well as information that has or may have economic value because it is not generally known or it is easily accessible to third parties who, through its use or disclosure, could achieve an economic benefit and who is protected by the company by appropriate measures in order to maintain its secrecy. " (2) So, from the technical aspect, it is a type of document in which there is a business secret which can be in the form of forms, drawings, procedures, etc. WIPO (World Intellectual Property Organization) defines a trade secret as:" any confidential business information that would provide an advantage to competition, and any unauthorized access to such information by third parties is considered unfair practice and a violation of trade secrets (3) (4, 76-83)." In the pharmaceutical industry, there is significant information related to new research and the planned development of a particular company. New research follows from in vitro to in vivo research, ie from laboratories through different phases of clinical trials (phases I to IV, postmarketing / epidemiological studies). From the aspect of business development, it is clear that global contract research organizations (sometimes parts of large pharmaceutical giants, and sometimes companies that operate independently) are a "big players" in the drug market, and thus their further directions in terms of business decision making and management present attractive information relevant to the competition. This information can be based on following: development strategy; standard operating procedures; research and development; penetration of new markets; change of course in the context of research indications; the opening of new departments etc.. The use of outsourcing services, as well as planning to download certain IT solutions and software can bring the company a certain advantage over competitors, but also can be considered as information that falls under business secrets definition (5, 203-207).

\section{METHODS OF CORPORATE ESPIONAGE}

In the Republic of Serbia, the Law on Protection of Business Secrets defines the following as illegal activities in the process of obtaining business secrets: "1) violation of contractual provisions on keeping business secrets; 2) abuse of business trust; 3) industrial or commercial espionage; 4) fraud; 5) reference to any action referred to in items 1) - 4) of this paragraph; 6) obtaining information that is a business secret by third parties who 
know or were obliged to know that this information is a business secret and that it was obtained from the person in whose legal possession it is. (6) " Methods of corporate espionage can be different. Both legal and illegal processes are used in the race for valuable information. In the literature, they are most often defined through the work of economic diplomats within the Embassy. $(1,87-92)$ There are various "tools" that an economic diplomat can use and they can be seen in active communication with companies, business lunches with company representatives, visits to production plants, attempts to break through the protective systems of companies on the Internet, etc. Among the riskier moves are certainly attempts to break into the "locked" sections of the company's website on the Internet, but also conversations with fired employees of the company whose information they are trying to obtain. This mode of action is not acceptable for the "host" country. $(1,87-92)$ In addition, there are even more risky processes of paying intermediaries to obtain information of importance and bribing employees in the firm in order to disclose such confidential information or techniques of purchasing classified documents (1, 87-92). As mentioned earlier, technolo-

Technological advances have enabled additional methods and tools for corporate espionage. gical advances have enabled additional methods and tools for corporate espionage. It is important to mention that many national interests are involved in the protection of information, as well as the use of information of importance, which is not owned by the state, and then through technological progress can see the growth of systems such as Echelon, a network of 120 satellites from the collection of military information to the collection of information of strategic and commercial importance, and there is also a German wiretapping station from the village of Bad Aibling codenamed "Big Ears" (7). In response to Echelon, the European Union launched the Galileo satellite network, which, when in its full capacity, will have 24 satellites and 6 orbit stations positioned at 23,000 $\mathrm{km}$ above the planet Earth. The creators of the Galileo system believe that the main difference is that Galileo is managed by the EU civil service, while in the case of the USA and Russia it is the military service (8). Hacker networks for downloading important information operate globally, and one of the control mechanisms is the employment of hackers in the process of testing or working on control mechanisms in the framework of software solutions or data encryption. In e-commerce, such intrusions are quite common, and for that reason there is a need for installation and constant innovation of protection systems (e.g. Fire wall). In this regard, in order to protect the data, it is necessary to have adequate technical performance of the system.

One of the well-known processes in corporate espionage, which is very attractive, is the employment of high-ranking staff from rival corporations and thus taking over a certain fund 
of their knowledge, but also information and contact networks. There is a well-known example of the "purchase" of the famous designer from Alfa Romeo (Walter de 'Silva, Wolfgang Egger) who designed the 156, Brera and other important models who "brought" the Alfa back to glory and then moved to work in a competitive VW. (1, 67-69)

Recently, in the pharmaceutical industry, there is a known case when 5 members of the team were arrested in the USA on suspicion that they worked in an organized manner to take over the trade secrets of the giant GlaxoSmithKlein pharmaceutical company in order to process information to their competitors. (9)

\section{CORPORATE ESPIONAGE IN PHARMACEUTICAL INDUSTRY}

Historically, industrial espionage appears to have been most prevalent within the military sector. Also, corporate espionage was "upgraded", so it continued in the aero industry sector, which is again connected to the military sector. There are known examples of such espionage at AIRBUS, 2015, and Concord, in the early 1980s. However, corporate espionage is also active within the biotech and pharmaceutical industries. However, the fact is that the biotechnology and pharmaceutical industries are advancing at a rapid pace. Namely, according to the data of EFPIA (European Federation of Pharmaceutical Industries and Associations), which is located in Brussels and which regularly monitors the development of this industry, we can see that within a very detailed analysis of ranking industrial sectors by research intensity and activity development (R\&D) in relation to the percentage of sales (R\&D as $a \%$ of sales), analyzed on a total of 2,500 companies from the EU (590 companies), Japan (356 companies), USA (837 companies), China (327 companies) and the rest of the world 390 companies) - the pharmaceutical and biotechnology industry ranks first (15\%). The software and computer services industry second (10.6\%), the IT sector - technology and hardware third $(8.4 \%)$, and the healthcare industry and service held fifth place $(4.4 \%)(10)$. Together, the pharmaceutical and biotechnology industries and the healthcare equipment and services industry have close to $20 \%$ of the value of their R\&D market. The geographical dispersion of clinical trials is also expanding. Image 2 shows that clinical trials are now being conducted in all parts of the world in accordance with the Standards of Good Clinical Practice (11). This has provided a number of advantages, both in terms of data diversity and benefits for patients for whom certain drugs or treatments are not available. 


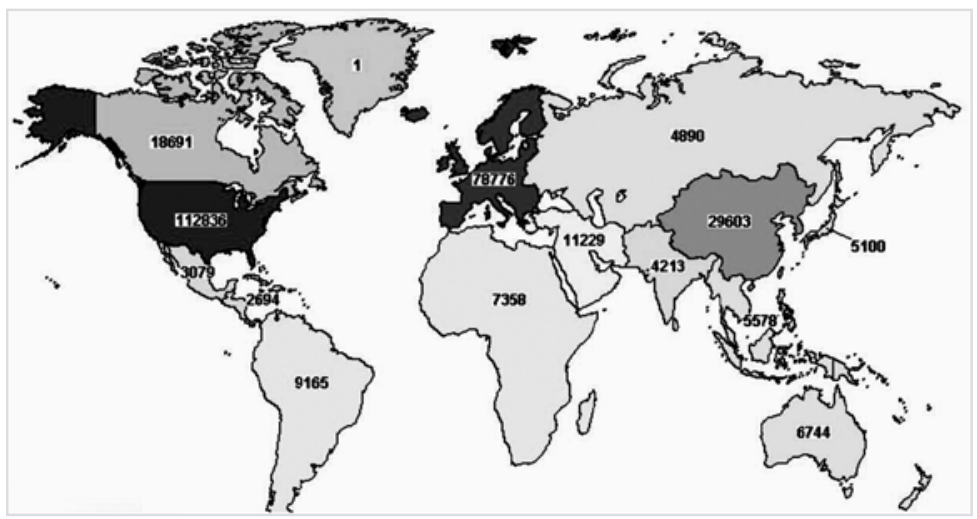

Image 1: Map of clinical trials in world, 2018 (11)

If we look at the aspect of the price of bringing a new drug to market, it is clear that the price is rising and has now reached approximately $\$ 2.5$ billion to bring a new drug to market. In the 1970s and early 1980s, the market price of the drug was about \$ 179 million; from the 1980s to the early 1990s - \$ 413 million; from the 1990s to the mid-1920s - \$1,044 million; and from the 1920s to the mid-2010s it exceeded \$ 2.5 billion. (4, 73-89) (11). The effects on price growth are, of course, not just of an inflationary nature. The increased quality and number of participants in the studies also led to the culmination of prices. Quality implies not only control mechanisms during the conduct of scientific research, but also numerous mechanisms of a regulatory nature that are established both before the beginning, during and after the end of scientific research. These mechanisms continue to monitor the product even after its arrival on the market when working on the collection of side effects and data relevant to the safety of use of a particular product (drug, medical device).

\section{RISKS IN THE PROCESS OF BRINGING INNOVATION TO THE MARKET IN PHARMACEUTICAL INDUSTRY}

In the process of bringing the drug to the market, there are a number of aggravating circumstances and it is necessary to prove the value and quality of the new product. Starting with in vitro research, then animal research, the tested product should go through all the phases of clinical trials that are very demanding in order to bring the product to market. Researchers who start research are very often forced to look for additional sources of funding so that they can go through all these phases. The cost of bringing a new drug to market is becoming more 
expensive as the drug approaches the marketing phase, so it is logical that if a drug does not prove adequate for marketing under phase III - leads to a significantly higher investment than when it occurs in earlier stages (e.g. in phase II) $(12,20-33)$. Recent research show the success rate of transition from one phase of clinical trial to another and it can be seen that the probability of success in transition from phase I to phase II is $63.2 \%$ (n $=3,582$ studies), and from the transition from Phase III to the NDA (New Drug Application) 58.1\% ( $\mathrm{n}=1,491$ studies) (4,8389). However, if the transition from phase II to phase III is observed $(30.7 \%, \mathrm{n}=3,862)$, the greatest risk can be noticed, and at the same time the greatest cost of studies. The overall risk of research and development of a new drug on a sample of 9,985 studies is $9.6 \%$, which is a relatively small percentage given the investments and complex clinical trial requirements to be met. Thus, less than $10 \%$ of clinical trials end up with a registered drug on the market $(4,83-89)$. This does not directly affect the number of patents that will be protected because drugs, mechanisms of action, methodology, etc. can be registered as a patent during research, and this is most often done at the very beginning (12, 20-33). Companies often fall into a financial crisis, but then recapitalizations can be done. The recapitalization of their companies can be done in various ways, and one of the most commonly accepted is through the search for new investors who would invest through the purchase of issued shares and enable further "life" for the research project.

However, despite all the difficulties, the medical technology industry has a constantly growing number of patents and according to the analysis conducted by the World Patent Protection Organization and the PCT (Patent Cooperation Treaty - Patent Cooperation Agreement), it records an increase in the number of patents by about 50\%, from 7,635 in 2004 to 15,016 in 2017. The biotechnology industry also achieved growth, from 5,858 patents registered in 2004 to 6,538 patents in 2017 . The pharmaceutical industry had 5,845 registered patents in 2004, and 8,747 in 2017 (13);(4,83-89).

\section{PATENT PROTECTION THROUGH THE WORK OF INTERNATIONAL ORGANIZATIONS}

WIPO defines a patent as the exclusive right to an invention, which may be a product or process that enables a new way of performing an action or provides a technical solution to a particular problem (14). In the case of the biomedical and pharmaceutical industries, the product is a drug (non-drug) or a medical device. The Paris Convention, concluded in 1883 and having 
undergone several revisions to date, the last being in 1967, relates largely to industrial property including patents, industrial design, applied models, geographical indications, and repression due to unfair competition. In accordance with this internationally recognized document, the following rules should be respected: "Patents from different countries for the same innovation are independent; A patent certificate should not be refused simply because the sale of a patent as a product is not permitted by national law (this segment is in line with the aforementioned patents for nonmarketing authorizations registered as patents); Contracting States may apply legislative measures to prevent abuses that may result from non-compliance with the exclusive right; Brand registration in one country has no impact on registration in another; A Member State should accept a request for the application of a new brand but does not have to adopt it if it does not comply with local regulations; Each Contracting State should deny the right to register and prohibit the use of brands containing reproductions, imitations, translations; Each Contracting State must provide effective protection against unfair competition. Patent protections provided by WIPO independently, but also in cooperation with the WTO and other organizations, are especially important for innovations in the medical industry, because such innovations involve large investments and large profits, and also carry great risks in the development process" (15, 193-198).

The TRIPS Agreement is the first international document defining the protection of clinical trial data submitted to regulatory bodies for the purpose of obtaining marketing authorization for the commercialization of a medicinal product (16). When a test substance is brought to market through clinical trials, then commercialization actually begins, in terms of the sale of health care products. The period of bringing the medicine to the market varies and ranges from 10 to 20 years. Also, the validity of exclusivity (i.e. patent rights) is 20 years, so a large number of companies actually lose a lot of time until they place the drug on the market $(17,265-269)$. According to the agreement initiated by the World Trade Organization - TRIPS - Agreement on Trade-Related Aspects of Intellectual Property Rights, exclusive patent rights are guaranteed to the product for a specified period of time and the production of generic products is not allowed, although they are cheaper and could contribute to global health benefits level, due to the price factor and thus greater accessibility for vulnerable groups (e.g. poor). Although access to generic products cannot be prevented, it is important that trademarks (owners of patents for pharmaceutical products), after the expiration of the patent protection period, must work diligently to strengthen marketing activities (18). When the right of exclusivity guaranteed by a patent expires, pharmaceutical companies must enter a strong race with ge- 
neric manufacturers, strengthening their marketing and sales strategies, in order to be able to secure an adequate and expected market share.

What is in some ways controversial within the framework of the agreement is the terminology of data exclusivity itself $(19 ; 175,184)$. The term itself is defined as "the protection of clinical trial data required for submission to a regulatory agency to prove the safety and efficacy of a new drug, and the prevention of the production of generic drugs based on this data in its applications" $(20 ; 825,840)$. Such data may include drug composition, method of manufacture, and potential health risks to humans, giving these data significant commercial value (21). Thus, this approach prevents generic drug manufacturers from entering generic drug production without initial costs in the research process (which we have stated can average up to $\$ 2.4$ billion) and thus bringing it to market. However, although it is ethically justified, even contained in important global documents such as the Declaration of Helsinki, or in the Paris Convention for the Protection of Industrial Property, when it comes to unfair competition, the fact can be considered that this approach to research data actually narrows the choice in drug access to populations from less developed countries.

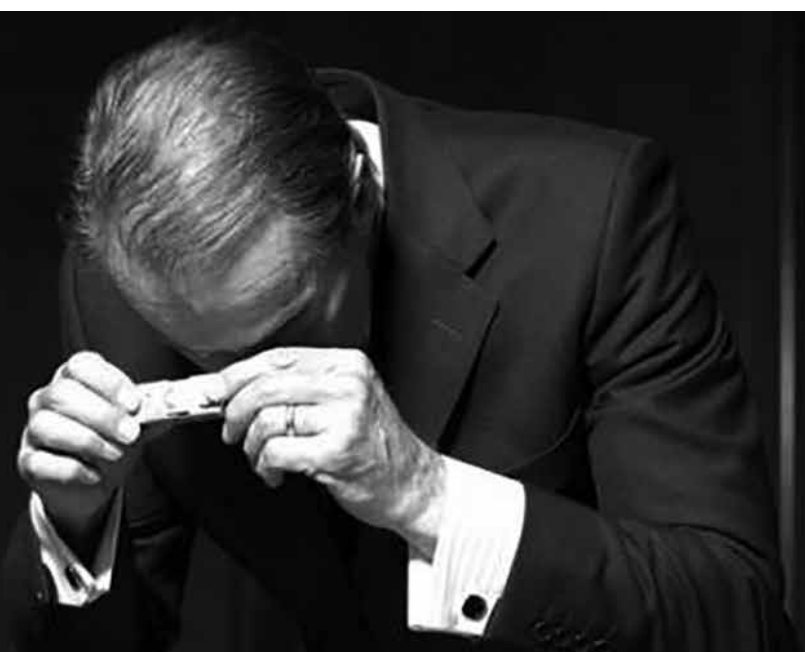


In addition, exclusivity in access and the right to use research data is limited to both the case in which the product was made and the case in which only a patent was registered but the product did not enter the market. In the first case, it will prevent the generic drug from appearing on the same market as the original drug, while in the second case it will prevent the product exclusivity from being defined, thanks to the patent, and thus prevent companies that produce it generics to go into further research or use data that could potentially contribute to their product coming to market.

Within the Agreement on Trade-Related Aspects of Intellectual Property Rights, Article 39, Section 7 - Protection of Unpublished Information, discusses the importance of protection against unfair competition as well as the protection of such information submitted to regulatory bodies. Natural and legal persons, as pointed out within the same article, should have the possibility of a legal remedy in case the exclusive data is used without authorization (22): "In case of secrecy, configuration or assembly of components; In case it has commercial value because it is a secret; When the person in control of the information has the right to declare the information as secret; Such measures indirectly affect the increase in the number of clinical trials due to the exclusivity of the data already performed by the patent holder". Thus, TRIPS has a stimulating effect on the development of research activities in clinical trials in several ways.

\section{PATENT PROTECTIONTHROUGH THE USE OF STANDARDS}

Standardization and protection of intellectual property such as patents is crucial for economic development and industrial competitiveness through the process of technology transfer (23). Effective standardization enables greater transparency on the one hand and greater data protection (security) on the other. Targeted groups in the process of standardization are companies, organizations, state institutions, citizens (consumers) and others. Thanks to (among other things) ISO (International organization for standardization) standardization, patent protection is increasing. Namely, in 2006, patent legislation was approved between ISO, IEC (International Standards and Conformity Assessment for all electrical, electronic and related technologies - International Standards for all electrical, electronic and related technologies). Through this cooperation, the efficiency and speed of information flow has increased. Improvements in solutions can be seen through the ISO 9000 and ISO 14000 standards. Also, it is important to note that ISO 10669: 2010 de- 
als with patent protection through brand evaluation including objectives, basis for evaluation, methods and quality data (23). ISO 12931: 2012 defines criteria for the evaluation of authentic solutions in order to establish the authenticity of the entire product life cycle (23). Also, there is ISO-DIS 20671, brand evaluation, which is currently under development as a standard.

\section{CONCLUSION}

The biotechnology and pharmaceutical industries have been growing steadily over the past decades, as evidenced by the numerous analyzes presented in this paper. The growth of the industry is noticeable in various aspects, and one of the most important for this work is the rate of investment in research and development. As the importance of the industry increases, so does the number of participants, and stronger competition. Unfair competition is willing to use different methods and use different tools in order to gain an advantage in the market. One of these methods important for this work is corporate espionage. The cost of bringing a new drug to market is enormous and has increased more than 10 times in the past few decades and it is expected to continue to grow. The success rate in bringing the drug to market is approximately $10 \%$. This speaks to an extremely expensive process, which is segmented and has an uncertain outcome. There are not many examples of corporate espionage in the pharmaceutical industry that escalated in public, but new ones are expected due to the accelerated development of the pharmaceutical and biotechnology industry. International organizations such as WIPO and WTO are largely involved in patent protection through the TRIPS agreement, which provides international protection for both the patent itself and the exclusivity of relevant information (trade secrets) resulting from clinical trials in the process of bringing patents to market.

\section{LITERATURE}

1. Prvulovic, V. Ekonomska diplomatija/Economic Diplomacy. Megatrend Univerzitet, Belgrade, 2002.

2. Official Gazette of Republic of Serbia, no. 36/2011 and 99/2011.

3. WIPO. Available at: http://www.wipo.int/sme/en/ip_business/trade_ secrets/trade secrets.htm, Accessed on: 20/12/2018.

4. Jelisavac Trošić S. Todić D. Stamenović M. Svetska trgovinska organizacija - životna sredina i sistem zdravstvene zaštite. Institut za međunarodnu politiku i privredu: Beograd; 2018.

5. Stamenovic M, Dobraca A. Benefits of Outsourcing Strategy and IT Technology in Clinical Trials. Acta Inform Med. 2017;25(3):203-207.

6. Zakon o zaštiti poslovne tajne/ the Law on Protection of Business Secrets. Official Gazette of Republic of Serbia 72/2011, article 8. 
7. Cryptogene. European Parliament. Available at: https://cr.yp.to/export/2001/09.07-europe.html, Accessed on: 05/12/ 2019.

8. GSA Europa. EGSA. Available at:https://www.gsa.europa.eu/european-gnss/galileo/galileo-european-global-satellite-based-navigation-system, Accessed on: 05/12/2019.

9. Reuters. Available at: https://fr.reuters.com/article/worldNews/ idUSKCN1U312I, Accessed on: 28/03/2020.

10. EFPIA. Available at: https://www.efpia.eu/publications/data-center/the-pharma-industry-in-figures-rd/rd-intensity/, Accessed on: 28/03/2020.

11. Clinicaltrials.gov. Available at: www.clinicaltrials.gov. Accessed on: 28/03/2020.

12. DiMasi, Joseph A., et al. "Innovation in the Pharmaceutical Industry: New Estimates of R\&D Costs." Journal of Health Economics, 2016.vol. 47.

13. Stamenovic M. Analiza ekonomskih podsticaja za razvoj kliničkih istraživanja unutar regiona. 7 Regionalna Konferencija o kliničkim ispitivanjima. Beograd;2017 http://www.lakodoleka.com/izvestajsa-sedme-redovne-konferencije-izazovi-u-klinickim-ispitivanjima-lekova/. Analize dostupne i putem literature pd rednim brojem (4).

14. WIPO. Available at: http://www.wipo.int/patents/en/, Accessed on: 05/07/2020.

15. Cuzovic S, Cuzovic Dj, Stamenovic M. Globalizacija -Savremeni aspekti ekonmije, trgovine i zdravstva. Ekonomski Fakultet Niš, Niš; 2019.

16. Marrakesh Agreement Establishing the World Trade Organization, 1867 UNTS 3, annex 1C, The Agreement on Trade Related Aspects of Intellectual Property Rights ('TRIPS Agreement').Available at: https://treaties.un.org/doc/Publication/UNTS/Volume\%201867/ volume-1867-I-31874-English.pdf, Accessed on: 05/07/2019.

17. Stamenović M, Gulan B, Dragaš B. Srbija danas - Savremeni aspekti neoliberalizma, ekonomije, demografije, zdravstva, bezbedosti i tranzicije, Prometej: Novi Sad, 2017.

18. Owoeye, O.A. Data Exclusivity and Public Health under the TRIPS Agreement. Journal of Law, Information and Science. 2014-2015. Vol 23(2).

19. Evans GE. Strategic Patent Licensing for Public Research Organizations: Deploying Restriction and Reservation Clauses to Promote Medical R\&D in Developing Countries. American Journal of Law and Medicine 2008.

20. Dwyer L. Patent Protection and Access to Medicine: The Colombia and Peruvian Trade Promotion Agreements. 13 Law \& Business Review of the Americas, 2007.

21. ZIS. Available at: http://www.zis.gov.rs/upload/documents/pdf_sr/ pdf/trips.pdf, Accessed on: 05/08/2020.

22. European Commission. Patents and Standards A modern framework for standardisation involving intellectual property rights, 2014.

23. ISO Available at: https://www.iso.org/standard/46032.html, Accessed on: 05/08/2020.

\section{TREBA LI OČEKIVATI POVEĆANJE KORPORATIVNE ŠPIJUNAŽE U FARMACEUTSKO] INDUSTRIJI U BUDUĆNOSTI?}

\section{REZIME}

Ključne reči: farmaceutska industrija, patentna zaštita, korporativna špijunaža

Korporativna špijunaža je postupak dobijanja poverljivih podataka od poslovnih konkurenata iz ekonomskih razloga i radi sticanja prednosti nad konkurencijom. Ovaj rad predstavlja analizu rasta industrije, ulaganja u istraživanje i razvoj i ukupnu vrednost ulaganja procenjujući moguće postojanje trendova i aktivnosti korporativne špijunaže $u$ industriji razvoja lekova. Neki autori analiziraju isplativost korporativne špijunaže u poređenju sa ulaganjem u istraživanje i razvoj, što ako se pokaže efikasnijim može biti odlučujući faktor za širenje zabranjenih aktivnosti. Rezultati analize pokazuju da bi se u budućnosti mogao očekivati rast korporativne špijunaže zbog sve većeg uticaja ovih industrija na društvo. 